\title{
An Empirical Study about the Intention to Hoard Food during COVID-19 Pandemic
}

\author{
Nguyen Ngoc Long ${ }^{1}$, Bui Huy Khoi ${ }^{1 *}$ \\ ${ }^{1}$ Industrial University of Ho Chi Minh City, VIETNAM \\ Received 2 April 2020 • Accepted 19 April 2020
}

\begin{abstract}
This study examines the expanded TPB model with the risk perception variable of intention to hoard food under the COVID-19 pandemic condition. All assumptions are supported by the traditional independent variables of the TPB model that affect the hoarding intention of food. However, the results of this study are completely different from previous studies when using the risk perception variable in the planned behavior theory model. In previous studies, the risk perception variable always negatively affected attitude and perceived behavior and buying intention. In this study, in contrast, the higher the risk perception the consumers get, the stronger the attitude the consumers purchase reserve goods. This demonstrates that a high-risk perception, in the case of COVID-19 pandemic or other civil unrests, will cause the intention to buy goods that no longer follows the common sense. This paper added a new perspective on the negative aspects of risk perception.
\end{abstract}

Keywords: COVID-19, hoard food, intention

\section{INTRODUCTION}

The COVID-19 pandemic started on December 31 last year in Wuhan city, Hubei province, China with many cases of severe pneumonia and has rapidly spread to other countries to become one of the largest catastrophes for the last ten years in the world. Since its start in Wuhan, different names have been generated for this deadly disease which was first called Corona, "Wuhan virus", "Chinese virus", and then officially named COVID-19 by WHO on February 11, 2020 (Ren, Gao, \& Chen, 2020). The microbe was, afterward, called Severe Acute Respiratory Syndrome Coronavirus 2, or COVID19 (Lai, Shih, Ko, Tang, \& Hsueh, 2020). 40 mutations of the coronavirus have been identified by the scientists in Iceland (Woods, 2020) to support an urgent need to control the panic of the rampant virus, causing the incessantly increasing numbers of cases and deaths reported in different countries every day. On March 11, 2020, the World Health Organization declared the global pandemic after the outbreak of the virus swept across countries all over the world and killed 4,200 people. Only three weeks later, on March 30, the coronavirus COVID-19 affected 199 countries and territories in six continents and 2 international conveyances, with 722,202 confirmed cases, and the death toll has increased more than 8 times, or 33,976 victims, while the numbers are continuing to rise rapidly (Worldometers, 2020). Despite being a country next to China and having patients infected by COVID-19 virus very early (the first case was reported on January 23, 2020), the Vietnamese government has considered being more effective in responding to the pandemic, and persistent efforts from a specialized government committee have been made to quell risks and minimize the transmission of infectious "germs". As of 30 March 2020, there were only 194 confirmed cases, no deaths so far inside the country, and 55 recoveries, while the majority of cases are foreigners, international students and travelers returning home from the affected countries (Wikipedia, 2020). Although the national strategy to protect individuals against health setbacks is running well and seems to have won the first battle in dealing with the pandemic. At the same time, many industries are facing difficulty surviving all perils and all aspects of the economy and society across the country are changing swiftly in response to the interruption of operations; services and productions have been suspended and many businesses are walking a dangerous line toward bankruptcy; consumption patterns are deforming in reaction to the threat of 


\section{Contribution to the literature}

- This paper employs The partial least squares structural equation model (PLS-SEM) to investigate the contribution of the TPB model that affect the hoarding intention of food.

- This paper that a high-risk perception, in the case of COVID-19 pandemic or other civil unrests, will cause the intention to buy goods that no longer follows the common sense.

- This paper added a new perspective on the negative aspects of risk perception.

shortage situations. Fearing an outbreak, many people went to supermarkets, traditional markets, and grocery stores to buy hoarding food, they bought so much that food stalls and some essential goods in selling places have been quickly emptied and become scarce even though the government has constantly communicated that there would always be a source of food for all people, even in the case of a prolonged lockdown. Otherwise, the governments of many countries taking nationalistic approaches have also restricted the sales of foodstuffs to prevent the domestic shortage of food sources during the pandemic. Kazakhstan stopped the exports of wheat flour, carrots, sugar, and potatoes; Serbia also stopped the selling of sunflower oil and some other goods; China is implementing a strategy of buying rice at high prices and in large quantities in neighboring countries to store long-term consumption; Kazakhstan stopped exporting buckwheat and onions; Countries in Southeast Asia also actively import rice and groceries with high prices as speculation (Isis, 2020). Thus, when hoarding occurs simultaneously in countries, the global food price system may set new relative highs, the global supply chain system may face the increase of global disruption risks, and policymakers may entwine with new instabilities in food security. The domino effect can easily link sequence activities of food reserve with the buying behavior of individuals to ensure safety for themselves and their families. The hoarding of people will, however, be able to increase the cost of the economy in dealing with the disease. Members of the society, who do not have a stable income and regularly have daily consumption habits, will soon panic after the supplies are exhausted and this may cause the risks of instability in society. Numerous previous studies have demonstrated that considering the behavior of individuals in society under conditions of social instability is essential both economically and sociologically (Bloom, De Wit, \& Carangal-San Jose, 2005; Cooper, 2006; Deng, Wang, \& Yousefpour, 2017; Kaigo, 2003; Kuo, Chen, Tseng, Ju, \& Huang, 2008; Wen, Huimin, \& Kavanaugh, 2005). Therefore, understanding the societal response to pandemic phenomena such as COVID-19 is an urgent requirement for scientists in this case.

This paper aims to examine the impact of the ongoing pandemic of coronavirus disease in 2019 on the food storage behavior of Vietnamese people. The study aimed to examine a theoretical model of the impact of Risk
Perception of COVID-19 on factors affecting food storage intention following the TPB model of Icek Ajzen (1991) and how it is applied in practice to prevent the national economical losses from the excessive food storage of individuals. The paper is also a theoretical basis for policymakers to identify the risks caused by the behaviors derived from panic and domino effect to the economies and provide countries a tool as an anti-crisis economic policy.

\section{LITERATURE REVIEW AND RESEARCH HYPOTHESES}

\section{The Theory of Planned Behavior Model and the Hoarding Behavior}

There has been an increasing interest in research the theories of planned behavior models in buying and selling intention with most highlighted theoretical models of Fishbein and Ajzen (1975), Icek Ajzen and Fishbein (1977), Fishbein and Ajzen (1980), I Ajzen (1985), Araujo (1985), Icek Ajzen (1991), Icek Ajzen (2011), and Conner and Sparks (2015). The Theory of Planned Behavior (TPB) model is an extension of the Theory of Reasoned Action (TRA) model of Fishbein and Ajzen (1975) and Fishbein and Ajzen (1980). These two models are widely used to evaluate individual decisionmaking behavior based on the information priorly collected to create the confidence basis for the behavioral intention. However, the TPB model is assessed as a more effective model in practice to evaluate and predict behavior (Hansen, Møller Jensen, \& Stubbe Solgaard, 2004) due to the high probability of success when conducting studies (Mimiaga, Reisner, Reilly, Soroudi, \& Safren, 2009). This model identifies three basic factors that affect an individual's intended behavior including attitude, subject norms, and perceived behavioral control. In making decisions in conditions of natural disasters or epidemics, many studies have used this model as a basic theory to understand consumers' buying intentions when the economy is unstable (e.g. Daellenbach, Parkinson, \& Krisjanous, 2018; Deng et al., 2017; Paton, 2003). Some studies add factors or incorporate elements into the model to effectively explain the relationships between the research variables (e.g Gkargkavouzi, Halkos, \& Matsiori, 2019; LópezMosquera \& Sánchez, 2012) and the research results of these studies have proved the hypotheses quite effectively, in particular, many previous studies have 
suggested adding environmental factors while studying the intention to generate an action of an individual (e.g. Chen \& Tung, 2014; D. Choi \& Johnson, 2019; Hsu \& Huang, 2012; Pavlou \& Fygenson, 2006).

Hoarding is defined as an effort to "accumulate large private stocks of goods when people perceive threats to supply" (Sterman \& Dogan, 2015), making the market possible to create phantom demand. The spike in orders could overload manufacturers and supply chains and businesses must increase production in the short term in the condition of passive and limited production resources. When the COVID-19 pandemic broke out, health products and commodities became seriously scarce because of the sudden increase in demand while raw materials and labor were deprived due to the stagnation of the supply chain system to prevent disease spread. Previous studies have shown that hoarding is explained in two theoretical aspects: operations and behavior (Sterman \& Dogan, 2015). Studies of operational aspects focus on resources to cope with material and labor shortages or the overload of logistics systems (e.g. T.-M. Choi, Chiu, \& Chan, 2016; KisperskaMoroń, 1989). Behavioral studies explain consumer hoarding based on personal experience and sentiment decisions (e.g. Deng et al., 2017; Sterman \& Dogan, 2015) and these decisions are often driven by psychological factors such as worries about depletion; scarcity of goods; anxiety about an individual's economic capacity that cannot meet the shortage situation when the deficiency occurs; and in particular, the panic caused by "herd behavior". When panic spread everywhere, consumers no longer act rationally, they always want to buy more than they need, the supply of goods will be unbalanced, many people cannot buy due to the empty of goods in selling places. The more they become panic, the more psychologically deprived it is in the market. As a result, the economic burden is on everyone because of the high cost of hoarding when social unrest emerges. This study continues to use the TPB model with three basic factors, including attitude, subject norms, and perceived behavior control, and take into account the impacts of Risk Perception of COVID-19 on other independent variables, before affecting Intention to hoard food.

\section{Risk Perception (RP)}

People use their emotions to assess risk, motivate action, and focus their thinking. These emotional influences are generally helpful, but can also be harmful (Van Bavel et al., 2020). First perceptional reactions to risky situations often diverge from cognitive evaluations and end up driving risk perceptions (Loewenstein, Weber, Hsee, \& Welch, 2001; Slovic, Finucane, Peters, \& MacGregor, 2013; Van Bavel et al., 2020). People rely on their feelings as a substitute for other information, such as the actual numeric risk. In this case, someone experiencing more negative perception during a pandemic will perceive a greater risk than if they experienced less negative emotion (Johnson \& Tversky, 1983). Emotions felt in response to a risky situation also influence the judgment in two stages (Peters, Lipkus, \& Diefenbach, 2006). First, the quality of emotion (e.g., positive vs negative) focuses the decisionmaker on congruent information. That information, rather than the feeling itself, is then used to guide judgment. For example, smokers exposed to more emotional health warnings experienced more negative emotion to the warnings and smoking, spent more time examining the warnings, and recalled more risks, with subsequent effects on risk perception and quit intentions (Van Bavel et al., 2020). In the case of COVID-19, as negative emotions increase, people may seek out and/or weigh negative information about COVID-19 more than others. Emotion also acts as a powerful motivator of behaviors(Frijda, 1986), such as socially isolating, and washing hands, but also hoarding supplies, and supporting harsh policies. The emotion's function as a direct motivator also means that, with strong perceptional reactions, people often ignore important numeric information such as probabilities (Rottenstreich \& Hsee, 2001) a problem's scope (Hsee \& Rottenstreich, 2004), and the effects of time (Peters, Kunreuther, Sagara, Slovic, \& Schley, 2012; Van Bavel et al., 2020). Risk perception is understood to be the degree to which mental acknowledgment perceives factors relating to potentially-hazardous activities or technologies determining people's risk judgments (Oltedal, Moen, Klempe, \& Rundmo, 2004). The importance of risk perception to the economy has been studied very early, since the study of Knight (2012) hundreds of years ago. To date, there have been many studies acknowledging the impact of risk perception on behavior in life, including consumer behavior. The measurement of the level of risk varies with each condition and the decisionmaking process of individuals is determined by the level of cost, benefit, level of damage, and level of risk appetite (Dowling \& Staelin, 1994). Previous studies have considered Risk Perception as an important factor influencing purchasing decisions (Lo, 2013) or purchasing intention (Lobb, Mazzocchi, \& Traill, 2007). Risk perception arises when food consumers intent whether it is safe or unsafe for physical health before making a buying decision of certain products (Kozup, 2017). Besides, when a product is consumed, the consumer's attitude is also affected by the awareness of risk factors such as financial risks, functional risks, social risks, psychological risks, and overall perceived risk (Jacoby \& Kaplan, 1972). These factors, along with Attitude, Subjective norm, Perceived behavior control influence the intention to consume a particular commodity (Lee, 2009; Quintal, Lee, \& Soutar, 2010). As early as the 1960s, Bauer (1960) asserted that consumer purchasing always contained a certain level of risk tolerance in the intention of buying and they anticipated 
a number of possible consequences with ability to cause certain losses and damages. Not long after that, Cox and Rich (1964) conducted a study on the impact of risk perception on telephone buying behavior with two factors: whether to buy or not to by products via Telephone and which ones shoud be ordered via Telephone. The results of the research sopported the affection of risk perception on Telephone buying. The study of Jacoby and Kaplan (1972) aslo showed that performance consequences are most predictive of overall perceived risk for most kinds of products. Futhermore, in the research of components to access perceived risk, Mitchell (1999) offered a general fomula:

\section{Risk $=\quad \begin{gathered}\text { Probability of } \\ \text { negative consequences }\end{gathered} \quad \mathrm{X} \quad \begin{gathered}\text { Importance of } \\ \text { negative consequences }\end{gathered}$}

From the above arithmetic, the risk is always equal to the possibility of damage and the importance of the consequences after the risk occurs. It indicates that when buyers intend to purchase a certain product, their behavior will be determined by the level of damage perception and the level of perceived achieving profit or benefit after the transaction. For example, in the study of Zhang, Yang, Cheng, and Luqman (2020), Risk perception harms the consumer attitude of poultry meat consumption. Fischer (2017) also pointed out that most previous studies on buying perceptions show that Risk Perception is negatively related to the perception of product benefits (e.g. Lee, 2009). However, in the study of Ulleberg and Rundmo (2003), the authors have shown that risk assessment is based not only on what the consumers understand about it but also on how they feel it. The emotion differences may increase the level of influence of risk perception on consumer behavior. During the COVID-19 pandemic, people felt that food safety risks, price risks, and product quality risks were all low and they felt a high risk of infection or lockdown , so their risk perception may be in the same direction as the attitude of hoarding purchases. Therefore, we construct a hypothesis:

H1: Risk perception has a positive effect on the Attitude of consumers in the plan to hoard food.

Risk perception is understood to be the degree to which mental acknowledgment perceives factors relating to potentially-hazardous activities or technologies determining people's risk judgments (Oltedal et al., 2004). The importance of risk perception to the economy has been studied very early, since the study of Knight (2012) hundreds of years ago. To date, there have been many studies acknowledging the impact of risk perception on behavior in life, including consumer behavior. The measurement of the level of risk varies with each condition and the decision-making process of individuals is determined by the level of cost, benefit, level of damage, and level of risk appetite (Dowling \& Staelin, 1994). Previous studies have considered Risk Perception as an important factor influencing purchasing decisions (Lo, 2013) or purchasing intention (Lobb et al., 2007). So we hypothesize that $\mathrm{H} 3$ as follows:

H3: The risk perception positively influences the Perceived Behavior of consumers in the plan to hoard food.

\section{Attitude (AT)}

In the TPB model, an attitude refers to an individual's attitude toward engaging in a particular behavior in question (Hamdah, Rahmadya, \& Nurlaela, 2020). According to the theory, attitude is a function of an individual's underlying beliefs regarding the outcomes that may be achieved by engaging in the behavior and the value they place on these outcomes. Several definitions of attitude have been written by several researchers, including attitudes defined as evaluating belief in both positive or negative feelings from someone if they have to do the behavior that will be determined. Meanwhile, attitude is a matter that learns about all tendencies of action, both beneficial and less favorable, human goals, objects, ideas, or situations. Attitude toward a behavior is determined by strong beliefs about their behavior (behavioral beliefs) which is the belief that an individual has towards a result of behavior and evaluation or results carried out (Hamdah et al., 2020). In Vietnam, assessing attitude toward coronavirus disease-2019 (COVID-19) among people. They showed good knowledge and a positive attitude(Huynh \& Nguyen, 2020). Thus, Hypothesis 4 indicates that:

H4: The attitude positively influences the Perceived Behavior of consumers in the plan to hoard food.

\section{Subjective Norm (SN)}

People's decisions are influenced by social norms as Subjective Norm: what they perceive others are doing or approve/disapprove (Cialdini \& Goldstein, 2004; Van Bavel et al., 2020). Informational influence occurs when people use others' behavior as input for reasonable interpretations and responses (Bikhchandani, Hirshleifer, \& Welch, 1998) and is stronger when people are uncertain and outcomes are important (Baron, Vandello, \& Brunsman, 1996). Normative influence occurs when people conform for social approval and is associated with more conformity in public than private (Sowden et al., 2018). Although people are influenced by perceptions of norms, their estimates of behavior are frequently inaccurate. For example, they underestimate health-promoting behaviors (e.g., handwashing (Dickie, Rasmussen, Cain, Williams, \& MacKay, 2018)) and overestimate unhealthy behaviors. Changing behaviors by correcting misperceptions is likely better achieved by public messages reinforcing health-promoting norms (e.g., common engagement in social distancing and hand-washing) rather than highlighting extreme / uncommon behaviors (e.g., panic buying, young adults gathering). Perceived norms and corrective information 


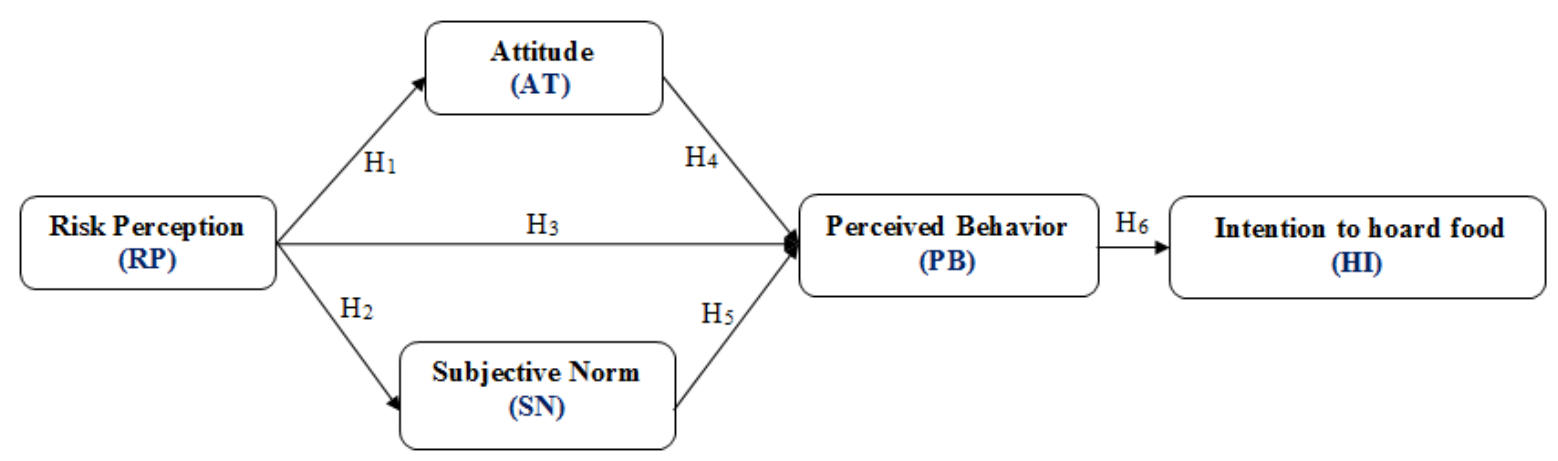

Figure 1. Investigation model

are most influential when specific to others with whom we share identities (Abrams, Wetherell, Cochrane, Hogg, \& Turner, 1990). This form of social influence can be problematic if it reduces learning from innovations in outgroups or if oppositional groups adopt different norms for partisan reasons (as we describe below in our section on polarization). Likewise, young adults' behaviors may be unaffected by information about how older adults are responding. If group divides produce different rates of conformity to health-protecting behaviors, we expect to see different rates of infection/mortality and greater difficulty containing the virus. Messages that provide ingroup models for norms (e.g., members of your community) may, therefore, be most effective. Hence, $\mathrm{H}_{2}$ and $\mathrm{H}_{5}$ are hypothesized as:

H2: The risk perception positively influences the Subjective Norm of consumers in the plan to hoard food.

H5: The subjective Norm positively influences the Perceived Behavior of consumers in the plan to hoard food.

\section{Perceived Behavior (PB)}

Perceived Behavior clarifies purchaser accumulating dependent on close to home understanding and sentiment decisions (e.g. Deng et al., 2017; Sterman \& Dogan, 2015) and these decisions are regularly determined by mental factors, for example, stresses over exhaustion; shortage of products; nervousness about a person's monetary limit that can't meet the lack circumstance when the insufficiency happens; and specifically the panic caused by "herd behavior". At the point when panic spread everywhere, customers never again act reasonably, they generally need to purchase more than they need, the inventory of products will be uneven, numerous individuals can't purchase because of the void of merchandise in selling places. The more they become panic, the more mentally denied it is in the market. Thus, the financial weight is on everybody because of the significant expense of hoarding when social unrest develops. So we give Hypothesis 6 as follows:

H6: The Perceived Behavior positively influences Hoarding Intention of consumers in the plan to hoard food.
From a theoretical basis, the research proposes the expected research model below.

\section{METHODOLOGY}

\section{Sample}

In this article, questionnaires were utilized to get information for examination. The quantitative investigation was an official study conducted in this research. The survey replied by respondents was the principal instrument to collate the information. The study was carried out in 2020 . The survey responded by respondents was the primary tool to obtain the data. The survey included questions about the status of the determinants that impacted the intention to hoard food during the COVID-19 pandemic. Respondents were selected by convenient methods with a sample size of 155 consumers living in Vietnam. There were 38 (24.5\%) males and 117 (75.5\%) females in this survey.

Their ages, income, and qualification were in Table 1 and Table 2.

A Likert-scale type survey was utilized to discover those determinants estimated from (1) "Strongly disagree" to (5) "Strongly agree".

\section{Structural Model Assessment}

The partial least squares structural equation model (PLS-SEM) model was created more than 20 years from the 1960s to 1980s. It was first started by Herman Wold and was progressed by his group (Lohmöller, 2013) Herman started with the advancement of a gathering of strategies that can take care of the least-squares relapse issues. During the 1980s, a few utilizations of the PLS technique were applied in financial aspects, sociologies and later was acquainted with science, which had high acknowledgment in established researchers (Vinzi, Chin, Henseler, \& Wang, 2010).

Interestingly with the covariance-based SEM, the PLS displaying doesn't expect that the factors are typically conveyed just as doesn't have the objective of lessening the contrast between the watched test change and the hypothetical model fluctuation, yet PLS demonstrating attempts to anticipate the needy factors of the develops. 
Table 1. Age groups and Working time

\begin{tabular}{lccccc}
\hline Age Groups & Amount & Percent (\%) & Income & Amount & Percent (\%) \\
\hline under 20 & 29 & 18.7 & Under VND 5 mill & 55 & 35.5 \\
From 20 to under 30 & 45 & 29.0 & From 5 to under VND 10 mill & 70 & 45.2 \\
From 30 to under 40 & 60 & 38.7 & From 10 to under VND 20 mill & 29 & 18.7 \\
From 40 to under 50 & 16 & 10.3 & Over VND 20 mill & 1 & 0.6 \\
Over 50 & 5 & 3.2 & Total & 155 & 100.0 \\
Total & 155 & 100.0 & & & \\
\hline
\end{tabular}

Table 2. Qualification

\begin{tabular}{lcc}
\hline Qualification & Amount & Percent $(\%)$ \\
\hline Diploma & 17 & 11.0 \\
Degree & 120 & 77.4 \\
Master & 18 & 11.6 \\
Total & 155 & 100.0 \\
\hline
\end{tabular}

The level of exactness of the model is assessed by the reinspecting of the information utilizing the expectation of mistakes. PLS doesn't utilize customary factual techniques for information that are gathered. The covariance-based SEM accepts that the information is gotten from a genuine and exact hypothetical model. The accentuation on the covariance-based model is to fit a model, and this makes a tight calculation that all information must be in rationality with the model. Covariance-based SEM must adjust with some measurable suspicions like the information appropriation. In any case, PLS accepts the deliberate information as a set that can be deciphered, not to fit the informational index to a hypothetical model.

We check our model on the authority datasets for the intention to hoard food during the COVID-19 pandemic. The dataset has five components of 155 consumers living in Vietnam, in the dataset. Data processing and statistical analyzing software utilized was Smartpls 3.0. The scale's reliability and validity were tested by Cronbach's alpha $(\alpha)$, average variance extracted $\left(\rho_{v c}\right)$, and composite reliability $\left(\rho_{c}\right)$. SEM was used to examine the model's hypotheses (Hair Jr, Hult, Ringle, \& Sarstedt, 2016; Klesel, Schuberth, Henseler, \& Niehaves, 2019). Cronbach's alpha coefficient higher than 0.6 would guarantee the scale's reliability (Nunnally \& Bernstein, 1994). Pc is better than 0.6 and $\rho_{v c}$ must be greater than 0.5. PLS-SEM is done on the theoretical framework. This strategy could control numerous autonomous components, in any event, when multicollinearity exists. PLS could be proceeded as a relapse model, predicting at least one ward factor from a lot of at least one free factor, or it very well may be finished as a way model. PLS could associate with the arrangement of autonomous elements to numerous reliant variables (Hair Jr et al., 2016).

\section{RESULTS}

\section{Measurement Model}

The measurement model evaluates the reliability and validity of the variables. Cronbach's alpha and composite reliability $\left(\mathrm{Pc}_{\mathrm{C}}\right)$ are taken to verify the construct's reliability (Henseler, Hubona, \& Ray, 2016). According to Hair Jr et al. (Hair Jr et al., 2016), Cronbach's alpha and Pc values should be more than 0.60 . However, this study found Cronbach's alpha and Pc between 0.961 to $0.801,0.972$ to 0.880 .

Moreover, according to Hair Jr et al. (Henseler et al., 2016), the values of Average Variance Extracted (Pvc) and rho_A should be more than 0.50 . The values of Pvc, rho_A have been recorded from 0.713 to $0.895,0.876$ to 0.961 . The results of the study are establishing convergent validity successfully. Hence the measurement model of the study validated successfully. The results of Cronbach's alpha, Pc, rho_A, and AVE can be seen in Table 3 .

Moreover, discriminant validity is used to validate the construct's external consistency. The discriminant validity evaluated on the bases of the Fornell-Larcker Criterion and HeterotraitMonotrait Ratio of Correlations (HTMT). According to Fornell-Larcker Criterion, the square roots of Pvc should be greater than other constructs vertically in a column. Besides, the HTMT index offers the latest criteria, this criteria is useful to measures the construct's external consistency (Henseler et al., 2016). This criterion is used to overcome the shortcoming in Fornell-Larcker Criterion and crossloadings.

However, the values of HTMT should not be greater than 1 (Henseler et al., 2016). Therefore, constructs have passed the validity test, all values have observed within the threshold limits, the result can be seen in Table 4 and Table 5.

Table 3. The reliability and validity

\begin{tabular}{lcccc}
\hline Construct & Cronbach's Alpha & rho_A & Composite Reliability (Pc) & Average Variance Extracted (Pvc) \\
\hline AT & 0.952 & 0.953 & 0.965 & 0.875 \\
HI & 0.960 & 0.961 & 0.971 & 0.892 \\
PB & 0.932 & 0.936 & 0.952 & 0.831 \\
RP & 0.801 & 0.876 & 0.880 & 0.713 \\
SN & 0.961 & 0.961 & 0.972 & 0.895 \\
\hline
\end{tabular}


Table 4. Fornell-Larcker Criterion

\begin{tabular}{|c|c|c|c|c|c|}
\hline Construct & $\mathrm{AT}$ & $\mathrm{HI}$ & $\mathrm{PB}$ & RP & SN \\
\hline$\overline{\mathrm{AT}}$ & 0.935 & & & & \\
\hline $\mathrm{HI}$ & 0.938 & 0.944 & & & \\
\hline PB & 0.881 & 0.849 & 0.912 & & \\
\hline RP & 0.531 & 0.481 & 0.585 & 0.844 & \\
\hline SN & 0.887 & 0.861 & 0.849 & 0.478 & 0.946 \\
\hline
\end{tabular}

Table 5. Heterotrait-Monotrait Ratio (HTMT)

\begin{tabular}{lcccc}
\hline Construct & AT & HI & PB & RP \\
\hline HI & 0.981 & & & \\
PB & 0.930 & 0.890 & 0.651 & 0.516 \\
RP & 0.580 & 0.522 & 0.892 & 0.897 \\
SN & 0.928 & 0 & \\
\hline
\end{tabular}

Table 6. The direct relationship between construct

\begin{tabular}{lccccc}
\hline Hypothesis & Beta & SD & T Values & P Values & Decision \\
\hline AT -> PB & 0.520 & 0.101 & 5.153 & 0.000 & Acceptance \\
PB -> HI & 0.849 & 0.033 & 25.876 & 0.000 & Acceptance \\
RP -> AT & 0.531 & 0.067 & 7.924 & 0.000 & Acceptance \\
RP -> PB & 0.161 & 0.048 & 3.335 & 0.001 & Acceptance \\
RP -> SN & 0.478 & 0.073 & 6.500 & 0.000 & Acceptance \\
SN -> PB & 0.310 & 0.089 & 3.476 & 0.001 & Acceptance \\
\hline
\end{tabular}

Note: $p<0.1^{*} p<0.05^{* *} p<0.01^{* * *}$ (Two Tail)

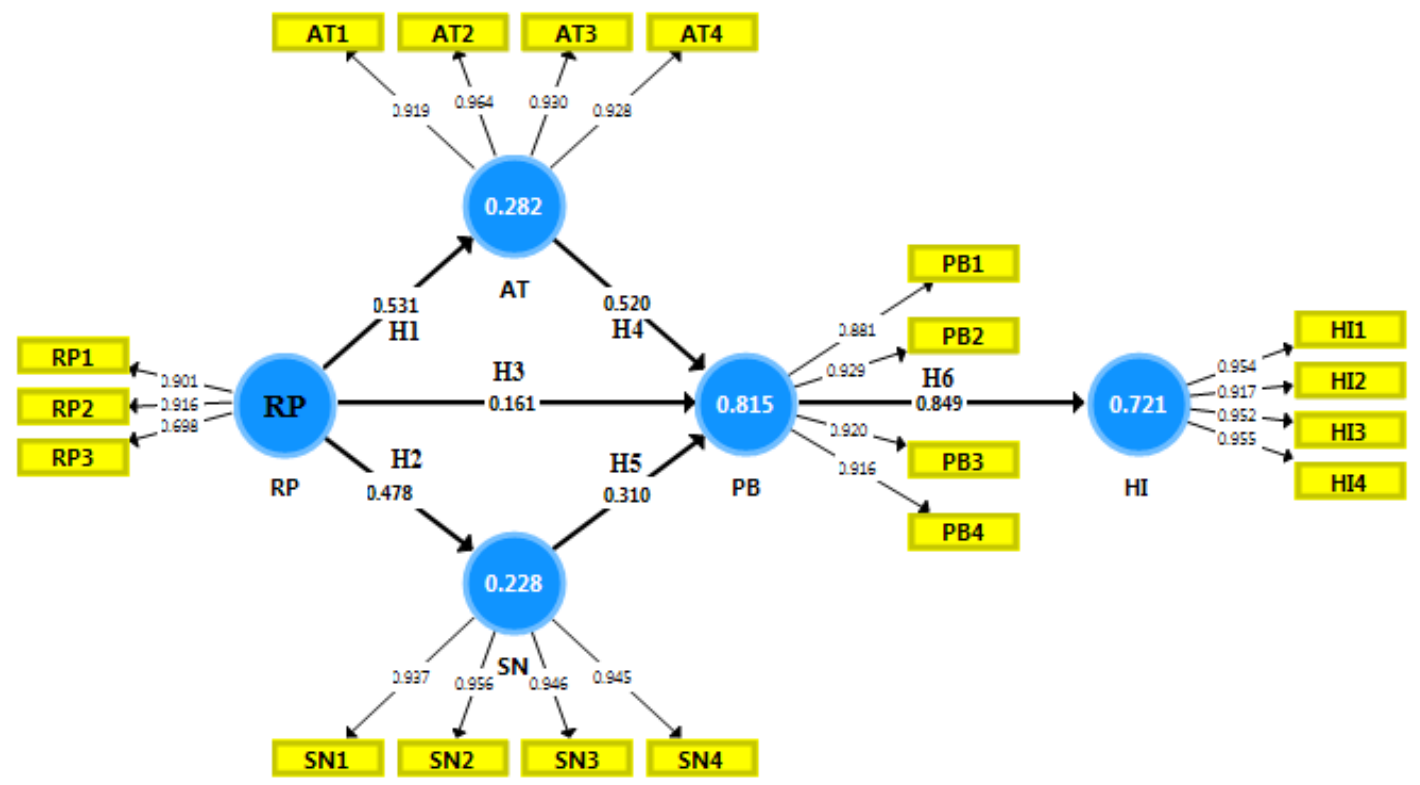

Figure 2. Structural Model

\section{Structural Model Assessment}

After the PLS algorithm, the study evaluated the structural model to make the final decision regarding hypothesis acceptance and rejection. The path coefficient used to verify the relationship between constructs.

In other words, partial least square (PLS) can be a regression model, which can handle the one or more dependent variables with a set of one or more independent variables, or it can be implemented as a path model. However, the bootstrapping technique has been used to run the PLS coefficient or path co-efficient.
The outcome of the significance level retrieved from the bootstrapping method, the $t$-value should be greater than 1.96 on the significance level of 0.05 . The present study has run the bootstrapping at 5000 sub-samples and retrieved the results; the results can be seen in Table 6 and Figure 2. All hypotheses are supported.

The coefficient of determination $\left(\mathrm{R}^{2}\right)$ is used to explain the model power. The value of $R^{2}$ is 0 to 1 ; the higher values present a higher determination. The $\mathrm{R}^{2}$ values such as $0.75,0.50$ and 0.25 are higher, moderated and small determination respectively. The $\mathrm{R}^{2}$ value of this model such as 0.721 is high. 
Table 7. Model fit

\begin{tabular}{lc}
\hline Indicator & Saturated model \\
\hline SRMR & 0.056 \\
d_ULS & 0.600 \\
d_G & 0.614 \\
Chi-Square & 517.661 \\
NFI & 0.871 \\
SRMR & 0.056 \\
\hline
\end{tabular}

The results in Table 7 revealed that the Chi-square $=$ 517.661 was significant at the 0.05 level $(p=0.00)$. SRMR (standardized root mean square residual) was a measure of the approximate model fit of the proposed research model. By convention, a model had a good model fit when SRMR was less than 0.08 (Hu \& Bentler, 1998). The report results in Table 7 disclosed that the model had SRMR indices $=0.056<0.08$. Consequently, the proposed research model was well suited for analysis data.

\section{CONCLUSION AND IMPLICATIONS}

\section{Conclusion}

In the pandemic caused by COVID-19, society will appear two groups of people with two opposing attitudes. Some people are highly thoughtless of scary information about the outbreak of deadly disease regardless of disease warnings. This group of people does not pay attention to the potential consequences of themselves and their residential society and this is the main cause of the disease spreading rapidly with the increasing number of infected people and deaths in many countries around the world every day. The remaining group has a fearful attitude and always actively avoids potential losses with a putative positive intelligence. However, in the group with a positive attitude to prevent the risks, there are always people who have an uncontrollable emotion of anxiety about the risks and may have violent acts such as concentrating all resources to store commodities, medicine, and food. As a result, panic buying will exacerbate fears about the flu, rising commodity prices beyond control and snatch goods install, supermarkets or shops, especially in big cities where the fresh food like fruits and vegetables are challenging to be self-sufficient. Another consequence is that people have hoarded so big quantity for a long time that a large amount of food would be able to get outdated and must be discarded (Carr, 2020). This has caused adversity that people who need cannot buy food, even though they can afford it while others may have to take it out because of the food's expiry date.

In this study, we used the TPB model in combination with the theory of consumer risk perception to understand the factors that affect the hoarding food behavior of people during the Covid19 pandemic. The questionnaire for sample collection in the study was conducted from March 15 to 30, 2020, sent to housewives, who were mostly responsible for the family's meals in Vietnam. Research results show that risk perception of the Covid19 pandemic has positively affected consumer attitudes towards the intention to keep stockpiling of food, which subsequently affected the intention to hoard the food of Vietnamese consumers.

When adding the risk perception variable to the TPB model, our study gave quite different results from previous studies - risk perception in this study had a positive impact on purchasing intention. When people carry out panicky behavior. It is quite easy to understand the behavior of panicky persons during the period of disaster. Let an earthquake, and people descend on stores across the big cities, trying to collect the clothes, food, and other commodities than they need in the lifetime. COVID 19 has been made the same thing again, people count on the others for their survival and they are willing to hoard food regardless the prices, quality, and even the short expiration dates; and of all of the kinds of food to be possessed as fast as possible, hoping to be safe in case of society lockdown or the spread of the pandemic. The reason is that people consider buying stocked food to be safer than not buying, despite the risks of high costs and other financial losses. This explains the buying behavior is strongly influenced by the psychology of consumers as shown in the study of (Lobb et al., 2007; Quintal et al., 2010; Sterman \& Dogan, 2015). When consumers perceive the greater benefits than the risk of the purchase, the greater the perceived risk is, the more motivation the people are willing to hoard (Mitchell, 1999). Contrary to the majority of previous studies' hypotheses, product risk perception almost has a negative relationship with purchasing intention (Fischer, 2017; Nam, 2019).

In this study, all hypotheses are supported. The perceived behavior variable has a strong impact on the intention of hoarding during the pandemic. In previous studies, this variable was also frequently confirmed to have a positive effect on purchasing behavior (). In our current research, perceived behavior has also had a strong influence on planned buying behavior. The risk of the spread of the COVID-19 pandemic is extremely worrying across countries, especially while the alarming dangerous levels are arising, governors of many different countries declare the states of emergency, and the shelves in supermarkets around the world become more and more empty. People now only care about how they can make a purchase, and the respondents in our survey seem to prioritize the product availability and the affordability as the leading factors (or perceived behavior) in their actual purchase intention. On the other hand, people who cannot afford to pay and perceived behavior is limited by the capacity to carry out their intention, they will not hoard food. This has also been demonstrated in the study of (Limayem, Hirt, \& Cheung, 
2007) when the capacity to perform a behavior is limited, the intention to consume will be reduced.

As expected, the Attitude and Subjective norm variables positively impacted the Perceived behavior control variables, which were $52 \%$ and $31 \%$, respectively. Besides, the Risk perception variable, which strongly affects Attitude (52.1\%) and Subjective Norm $(47.8 \%)$, only affects $16.1 \%$ on Perceived behavior. This demonstrates that when consumers perceive strongly the risks of a pandemic, they can influence the beliefs of those around them about the risks they are facing, and it also promotes their attitude to cope with threats from the external environment. Then, in turn, the attitude towards consumers' intention to engage a certain activity has a strong impact on their own perceived behavior. The study results also showed that Perceived behavior received the lowest impact from the Attitude of consumers. This may easily explain that people can aware of the rising risk of the pandemic, but they perceive the difficulty to conduct the behavior so. As a result, the impact of Risk Perception on Perceived behavior is not as strong as that on other variables.

\section{Implications}

What is important to do while society is unstable is how we try to handle it. Governments and policymakers need to understand positive behaviors and encourage behaviors that minimize damage, and to convince people to understand and limit actions that may increase the crisis and panic during the pandemic. The biggest difficulty for governments is that people are always affected by their psychology and belief in negative things that can happen in the future. The increasing purchase of hoarding goods makes the shelves in supermarkets empty. When consumers' perceived behavior is influenced by attitudes, subjective norms, and risk perception, their intention to hoard food during the pandemic may even intensify, even though they are aware of market instability and other consequences caused by stockpiling.

In the civil unrest condition of society like an ongoing pandemic, the government should reduce people's perceived behavioral with appropriate policies such as making goods available in supermarkets, formulate policies to prevent uncontrolled price manipulation and price increase, and enhance communication to persuade people not to buy too much reserve goods. Besides, governments should focus on increasing the circulation of commodity commodities from rural to urban areas, instead of focusing on pumping more money into society, causing prices to be pushed further up but goods are still scarce.

\section{Limitations and Future Recommendations}

Risk perception, shown by the study of Ulleberg and Rundmo (2003), related to personality traits and hazards
(Barnett \& Breakwell, 2001). For example, the study of Ulleberg and Rundmo (2003) shows that perceived risk has a positive effect on aggressiveness and negative effect on Normlessness. In terms of time constraints, this study has not been able to add variables in the personality model into the study because it will require a larger study scale and time. So many questions in a survey may reduce the survey quality (Kitchenham \& Pfleeger, 2002) because respondents have to take a long time to answer the questions and feel confused.

Future studies, when evaluating consumer behavior, need to be carried out with psychological variables that have a strong influence on individual behavior. Also, future research needs to consider the civil unrest variable as a moderator variable, which can change the buying intention from positive to negative or vice versa. The lack of propaganda in national policies to control pandemic may also be a factor that raises people's panicky hoarding intentions that future studies should pay attention to.

\section{ACKNOWLEDGMENTS}

This work was supported in part by Industrial University of Ho Chi Minh City, Vietnam.

\section{REFERENCES}

Abrams, D., Wetherell, M., Cochrane, S., Hogg, M. A., \& Turner, J. C. (1990). Knowing what to think by knowing who you are: Self-categorization and the nature of norm formation, conformity and group polarization. British journal of social psychology, 29(2), 97-119. https:/ / doi.org/10.1111/j.2044-8309. 1990.tb00892.x

Ajzen, I. (1985). From intentions to actions: A theory of planned behaviour. From cognition to behaviour (pp. 11-39): Actionocontrol. https://doi.org/10.1007/ 978-3-642-69746-3_2

Ajzen, I. (1991). The theory of planned behavior. Organizational behavior and human decision processes, 50(2), 179-211. https://doi.org/10.1016/0749-5978 (91)90020-T

Ajzen, I. (2011). The theory of planned behaviour: reactions and reflections: Taylor \& Francis. https:/ / doi.org/10.1080/08870446.2011.613995

Ajzen, I., \& Fishbein, M. (1977). Attitude-behavior relations: A theoretical analysis and review of empirical research. Psychological bulletin, 84(5), 888. https://doi.org/10.1037/0033-2909.84.5.888

Araujo, M. J. T. (1985). Theories of export behaviour: a critical analysis. Journal of Marketing, 19(2), 42-52. https:// doi.org/10.1108/EUM0000000004751

Barnett, J., \& Breakwell, G. M. (2001). Risk perception and experience: Hazard personality profiles and individual differences. Risk Analysis, 21(1), 171-178. https:/ / doi.org/10.1111/0272-4332.211099 
Baron, R. S., Vandello, J. A., \& Brunsman, B. (1996). The forgotten variable in conformity research: Impact of task importance on social influence. Journal of personality and Social Psychology, 71(5), 915. https:/ / doi.org/10.1037/0022-3514.71.5.915

Bauer, R. A. (1960). Consumer behavior as risk taking. Chicago, IL, 384-398.

Bikhchandani, S., Hirshleifer, D., \& Welch, I. (1998). Learning from the behavior of others: Conformity, fads, and informational cascades. Journal of economic perspectives, 12(3), 151-170. https://doi.org/ $10.1257 /$ jep.12.3.151

Bloom, E., De Wit, V., \& Carangal-San Jose, M. J. (2005). Potential economic impact of an avian flu pandemic on Asia.

Carr, J. (2020). 'The madness continues': Social media users slam 'wasteful' panic-buyers who are still throwing away perfectly good food after stockpiling more than they can consume. MAILONLINE. Retrieved from https:/ / www.daily mail.co.uk/news/article-8168489/Social-mediausers-slam-wasteful-panic-buyers-throwing-awayperfectly-good-food.html

Chen, M.-F., \& Tung, P.-J. (2014). Developing an extended theory of planned behavior model to predict consumers' intention to visit green hotels. International journal of hospitality management, 36, 221-230. https://doi.org/10.1016/j.ijhm.2013.09. 006

Choi, D., \& Johnson, K. K. (2019). Influences of environmental and hedonic motivations on intention to purchase green products: An extension of the theory of planned behavior. Sustainable Production and Consumption, 18, 145-155. https://doi.org/10.1016/j.spc.2019.02.001

Choi, T.-M., Chiu, C.-H., \& Chan, H.-K. (2016). Risk management of logistics systems: Elsevier. https: / / doi.org/10.1016/j.tre.2016.03.007

Cialdini, R. B., \& Goldstein, N. J. (2004). Social influence: Compliance and conformity. Annu. Rev. Psychol., 55, 591-621. https://doi.org/10.1146/annurev. psych.55.090902.142015

Conner, M., \& Sparks, P. (2015). Theory of planned behaviour and the reasoned action approach.

Cooper, M. (2006). Japanese tourism and the SARS epidemic of 2003. Journal of Travel $\mathcal{E}$ Tourism Marketing, 19(2-3), 117-131. https://doi.org/ $10.1300 / J 073 v 19 n 02 \_10$

Cox, D. F., \& Rich, S. U. (1964). Perceived risk and consumer decision-making - the case of telephone shopping. Journal of marketing research, 1(4), 32-39.

Daellenbach, K., Parkinson, J., \& Krisjanous, J. (2018). Just how prepared are you? An application of marketing segmentation and theory of planned behavior for disaster preparation. Journal of nonprofit $\mathcal{E}$ public sector marketing, 30(4), 413-443. https:/ / doi.org/10.1080/10495142.2018.1452830

Deng, Y., Wang, M., \& Yousefpour, R. (2017). How do people's perceptions and climatic disaster experiences influence their daily behaviors regarding adaptation to climate change? - A case study among young generations. Science of the total environment, 581, 840-847. https://doi.org/ 10.1016/j.scitotenv.2017.01.022

Dickie, R., Rasmussen, S., Cain, R., Williams, L., \& MacKay, W. (2018). The effects of perceived social norms on handwashing behaviour in students. Psychology, health $\mathcal{E}$ medicine, 23(2), 154-159. https:/ / doi.org/10.1080/13548506.2017.1338736

Dowling, G. R., \& Staelin, R. (1994). A model of perceived risk and intended risk-handling activity. Journal of consumer research, 21(1), 119-134. https:/ / doi.org/10.1086/209386

Fischer, A. R. (2017). Perception of product risks Consumer perception of product risks and benefits (pp. 175-190): Springer. https:/ / doi.org/10.1007/978-3319-50530-5_9

Fishbein, M., \& Ajzen, I. (1975). Belief, Attitude, Intention, and Behavior. A Social Cognitive Theory: Addison-Wesley Reading, MA.

Fishbein, M., \& Ajzen, I. (1980). Understanding attitudes and predicting social behavior.

Frijda, N. H. (1986). The emotions: Cambridge University Press.

Gkargkavouzi, A., Halkos, G., \& Matsiori, S. (2019). Environmental behavior in a private-sphere context: Integrating theories of planned behavior and value belief norm, self-identity and habit. Resources, Conservation and Recycling, 148, 145-156. https:/ / doi.org/10.1016/j.resconrec.2019.01.039

Hair Jr, J. F., Hult, G. T. M., Ringle, C., \& Sarstedt, M. (2016). A primer on partial least squares structural equation modeling (PLS-SEM): Sage Publications. https:/ / doi.org/10.15358/9783800653614

Hamdah, D. F. L., Rahmadya, R. R., \& Nurlaela, L. (2020). The Effect of Attitude, Subjective Norm, and Perceived Behavior Control of Taxpayer Compliance of Private Person in Tax Office Garut, Indonesia. Review of Integrative Business and Economics Research, 9, 298-306.

Hansen, T., Møller Jensen, J., \& Stubbe Solgaard, H. (2004). Predicting online grocery buying intention: a comparison of the theory of reasoned action and the theory of planned behavior. International Journal of Information Management, 24(6), 539-550. https:/ / doi.org/10.1016/j.ijinfomgt.2004.08.004

Henseler, J., Hubona, G., \& Ray, P. A. (2016). Using PLS path modeling in new technology research: 
updated guidelines. Industrial management $\mathcal{E}$ data systems, 116(1), 2-20. https://doi.org/10.1108/ IMDS-09-2015-0382

Hsee, C. K., \& Rottenstreich, Y. (2004). Music, pandas, and muggers: on the affective psychology of value. Journal of Experimental Psychology: General, 133(1), 23. https:/ / doi.org/10.1037/0096-3445.133.1.23

Hsu, C. H., \& Huang, S. (2012). An extension of the theory of planned behavior model for tourists. Journal of Hospitality E Tourism Research, 36(3), 390417. https:/ / doi.org/10.1177/1096348010390817

$\mathrm{Hu}$, L.-T., \& Bentler, P. M. (1998). Fit indices in covariance structure modeling: Sensitivity to underparameterized model misspecification. Psychological methods, 3(4), 424. https://doi.org/ 10.1037/1082-989X.3.4.424

Huynh, G., \& Nguyen, T. N. H. (2020). Knowledge and attitude toward COVID-19 among healthcare workers at District 2 Hospital, Ho Chi Minh City. Asian Pacific Journal of Tropical Medicine. https:/ / doi.org/10.4103/1995-7645.280396

Isis, A. A., de Sousa. (2020). Countries Starting to Hoard Food, Threatening Global Trade. Bloomberg.

Jacoby, J., \& Kaplan, L. B. (1972). The components of perceived risk. ACR Special Volumes.

Johnson, E. J., \& Tversky, A. (1983). Affect, generalization, and the perception of risk. Journal of personality and Social Psychology, 45(1), 20. https:/ / doi.org/10.1037/0022-3514.45.1.20

Kaigo, M. (2003). Initial Findings in the Perceptions and Behavioural Change by News on SARS in Japan. Media Asia, 30(4), 216-219. https://doi.org/ 10.1080/01296612.2003.11726728

Kisperska-Moroń, D. (1989). The influence of material inventories on materials requirements in Polish engineering industry - Let's try business logistics. Engineering Costs and Production Economics, 15, 7579. https:/ / doi.org/10.1016/0167-188X(89)90105-5

Kitchenham, B. A., \& Pfleeger, S. L. (2002). Principles of survey research: part 3: constructing a survey instrument. ACM SIGSOFT Software Engineering Notes, 27(2), 20-24. https://doi.org/10.1145/ 511152.511155

Klesel, M., Schuberth, F., Henseler, J., \& Niehaves, B. (2019). A test for multigroup comparison using partial least squares path modeling. Internet research, 29(3), 464-477. https://doi.org/10.1108/ IntR-11-2017-0418

Knight, F. H. (2012). Risk, uncertainty and profit: Courier Corporation.

Kozup, J. (2017). Risks of Consumer Products Consumer Perception of Product Risks and Benefits (pp. 23-38): Springer. https://doi.org/10.1007/978-3-319-5053 $0-5 \_2$
Kuo, H.-I., Chen, C.-C., Tseng, W.-C., Ju, L.-F., \& Huang, B.-W. (2008). Assessing impacts of SARS and Avian Flu on international tourism demand to Asia. Tourism Management, 29(5), 917-928. https:/ / doi.org/10.1016/j.tourman.2007.10.006

Lai, C.-C., Shih, T.-P., Ko, W.-C., Tang, H.-J., \& Hsueh, P.-R. (2020). Severe acute respiratory syndrome coronavirus 2 (COVID-19) and corona virus disease-2019 (COVID-19): the epidemic and the challenges. International journal of antimicrobial agents, 105924. https://doi.org/10.1016/ j.ijantimicag.2020.105924

Lee, M.-C. (2009). Factors influencing the adoption of internet banking: An integration of TAM and TPB with perceived risk and perceived benefit. Electronic Commerce Research and Applications, 8(3), 130-141. https://doi.org/10.1016/j.elerap.2008.11. 006

Limayem, M., Hirt, S. G., \& Cheung, C. M. (2007). How habit limits the predictive power of intention: The case of information systems continuance. MIS quarterly, 705-737. https://doi.org/10.2307/ 25148817

Lo, A. Y. (2013). The role of social norms in climate adaptation: Mediating risk perception and flood insurance purchase. Global Environmental Change, 23(5), 1249-1257. https://doi.org/10.1016/ j.gloenvcha.2013.07.019

Lobb, A., Mazzocchi, M., \& Traill, W. (2007). Modelling risk perception and trust in food safety information within the theory of planned behaviour. Food quality and preference, 18(2), 384-395. https:// doi.org/10.1016/j.foodqual.2006.04.004

Loewenstein, G. F., Weber, E. U., Hsee, C. K., \& Welch, N. (2001). Risk as feelings. Psychological bulletin, 127(2), 267. https://doi.org/10.1037/0033-2909. 127.2.267

Lohmöller, J.-B. (2013). Latent variable path modeling with partial least squares: Springer Science \& Business Media.

López-Mosquera, N., \& Sánchez, M. (2012). Theory of Planned Behavior and the Value-Belief-Norm Theory explaining willingness to pay for a suburban park. Journal of environmental management, 113, 251-262. https://doi.org/10.1016/j.jenvman. 2012.08.029

Mimiaga, M. J., Reisner, S. L., Reilly, L., Soroudi, N., \& Safren, S. A. (2009). Individual interventions HIV Prevention (pp. 203-239): Elsevier. https:/ / doi.org/ 10.1016/B978-0-12-374235-3.00008-X

Mitchell, V. W. (1999). Consumer perceived risk: conceptualisations and models. European Journal of marketing. https://doi.org/10.1108/030905699102 49229 
Nam, N. K., Nguyen Thi Hang Nga, \& Ngo Quang Huan. (2019). The Consumers' Intention to Purchase Food: The Role of Perceived Risk. Academy of Strategic Management Journal, 18(1).

Nunnally, J. C., \& Bernstein, I. (1994). The assessment of reliability. Psychometric theory, 3(1), 248-292.

Oltedal, S., Moen, B.-E., Klempe, H., \& Rundmo, T. (2004). Explaining risk perception: An evaluation of cultural theory. Trondheim: Norwegian University of Science and Technology, 85(1-33), 86.

Paton, D. (2003). Disaster preparedness: a socialcognitive perspective. Disaster Prevention and Management: An International Journal. https:/ / doi.org/10.1108/09653560310480686

Pavlou, P. A., \& Fygenson, M. (2006). Understanding and predicting electronic commerce adoption: An extension of the theory of planned behavior. MIS quarterly, 115-143. https://doi.org/10.2307/ 25148720

Peters, E., Kunreuther, H., Sagara, N., Slovic, P., \& Schley, D. R. (2012). Protective measures, personal experience, and the affective psychology of time. Risk Analysis: An International Journal, 32(12), 20842097. https://doi.org/10.1111/j.1539-6924.2012. 01810.x

Peters, E., Lipkus, I., \& Diefenbach, M. A. (2006). The functions of affect in health communications and in the construction of health preferences. Journal of communication, 56, S140-S162. https://doi.org/ 10.1111/j.1460-2466.2006.00287.x

Quintal, V. A., Lee, J. A., \& Soutar, G. N. (2010). Risk, uncertainty and the theory of planned behavior: A tourism example. Tourism Management, 31(6), 797805. https://doi.org/10.1016/j.tourman.2009.08. 006

Ren, S.-Y., Gao, R.-D., \& Chen, Y.-L. (2020). Fear can be more harmful than the severe acute respiratory syndrome coronavirus 2 in controlling the corona virus disease 2019 epidemic. World Journal of Clinical Cases, 8(4), 652. https://doi.org/10.12998/ wjcc.v8.i4.652

Rottenstreich, Y., \& Hsee, C. K. (2001). Money, kisses, and electric shocks: On the affective psychology of risk. Psychological science, 12(3), 185-190. https:/ / doi.org/10.1111/1467-9280.00334

Slovic, P., Finucane, M. L., Peters, E., \& MacGregor, D. G. (2013). Risk as analysis and risk as feelings: Some thoughts about affect, reason, risk and rationality The Feeling of Risk (pp. 49-64): Routledge. https:/ / doi.org/10.4324/9781849776677

Sowden, S., Koletsi, S., Lymberopoulos, E., Militaru, E., Catmur, C., \& Bird, G. (2018). Quantifying compliance and acceptance through public and private social conformity. Consciousness and cognition, 65, 359-367. https://doi.org/10.1016/ j.concog.2018.08.009

Sterman, J. D., \& Dogan, G. (2015). “I'm not hoarding, I'm just stocking up before the hoarders get here.": Behavioral causes of phantom ordering in supply chains. Journal of Operations Management, 39-40, 622. https:/ / doi.org/10.1016/j.jom.2015.07.002

Ulleberg, P., \& Rundmo, T. (2003). Personality, attitudes and risk perception as predictors of risky driving behaviour among young drivers. Safety science, 41(5), 427-443. https://doi.org/10.1016/S09257535(01)00077-7

Van Bavel, J. J., Boggio, P., Capraro, V., Cichocka, A., Cikara, M., Crockett, M., . . . Drury, J. (2020). Using social and behavioural science to support COVID19 pandemic response. https://doi.org/10.31234/ osf.io/y38m9

Vinzi, V. E., Chin, W. W., Henseler, J., \& Wang, H. (2010). Handbook of partial least squares (Vol. 201): Springer. https: / / doi.org/10.1007/978-3-540-32827-8

Wen, Z., Huimin, G., \& Kavanaugh, R. R. (2005). The impacts of SARS on the consumer behaviour of Chinese domestic tourists. Current Issues in Tourism, 8(1), 22-38. https://doi.org/10.1080/136835005 08668203

Wikipedia. (2020). 2020 coronavirus pandemic in Vietnam.

Woods, A. (2020, March 24, 2020). Iceland scientists found 40 mutations of the coronavirus, report says. NYPost.

Worldometers. (2020). COVID-19 Coronavirus Pandemic. from https:/ / www.worldometers.info/ coronavirus/

Zhang, Y., Yang, H., Cheng, P., \& Luqman, A. (2020). Predicting consumers' intention to consume poultry during an H7N9 emergency: an extension of the theory of planned behavior model. Human and Ecological Risk Assessment: An International Journal, 26(1), 190-211. https://doi.org/10.1080/ 10807039.2018.1503931

\section{http://www.ejmste.com}

